\title{
Bronchial atresia with finger-in-glove sign
}

\author{
Burhan Apiliogullari, ${ }^{1}$ Mehmet Yavşan ${ }^{2}$
}

1 Department of Thoracic Surgery, Necmettin Erbakan University, Meram Medical Faculty, Konya, Turkey ${ }^{2}$ Department of Chest Diseases, Necmettin Erbakan University, Meram Medical Faculty, Konya, Turkey

\section{Correspondence to} Dr Burhan Apiliogullari, bapiliogullari@yahoo.com

Accepted 6 April 2014
To cite: Apiliogullari $B$, Yavşan M. BMJ Case Rep Published online: [please include Day Month Year] doi:10.1136/bcr-2014204587

\section{DESCRIPTION}

During a routine examination for a smoking cessation programme, a 32-year-old asymptomatic man was found to have rounded, branching opacity in the left upper lung on chest X-ray (figure 1). Contrast-enhanced CT revealed a dilated central bronchus (bronchocele) in the left upper lobe with mucous impaction of the peripheral bronchi in a branching pattern (finger-in-glove sign). In addition, the presence of segmental hyperlucency in the surrounding lung parenchyma strongly suggested the diagnosis of congenital bronchial atresia (figure 2). As the patient did not have any symptoms, he was followed up without receiving any treatment.

Bronchial atresia is mostly an incidental radiographic finding in young and adult men that results from focal interruption of a segmental and subsegmental bronchus due to intrauterine ischaemia. ${ }^{12}$ It is associated with focal discontinuity of a bronchus, mucus impaction within the distal airways (bronchocele) and increased attenuation of the obstructed pulmonary segment due to collateral ventilation through the intra-alveolar pores of Kohn and the bronchoalveolar channels of Lambert. $^{2}{ }^{3}$ Most of the cases are asymptomatic. Symptomatic patients may present with pulmonary infections, mild wheezing and dyspnoea. If necessary, surgically treatment with parenchymal-sparing segmentectomy (or lobectomy) should be considered in these individuals. ${ }^{2}$

On chest X-rays or CT images, the branching dilated airways that are filled with respiratory secretions and that radiate from the hilum towards the periphery of the lung are described as being a finger-in-glove sign. ${ }^{1-3}$ It is a relatively common finding in bronchial atresia, but it is also associated with a wide variety of diseases of both congenital

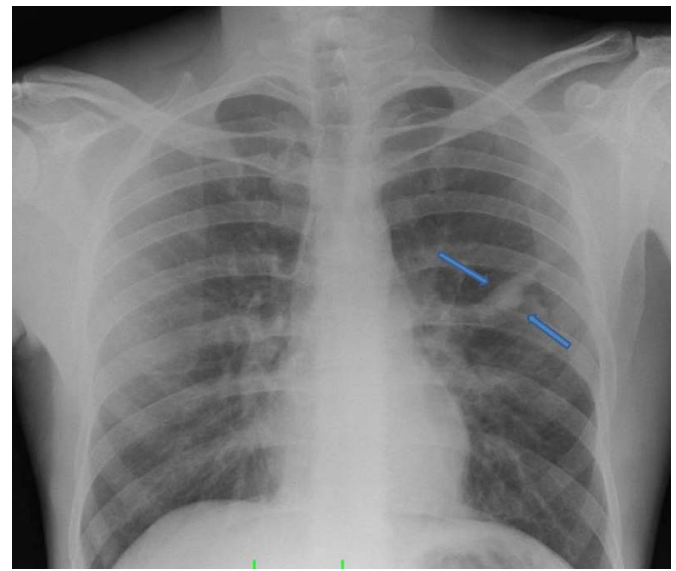

Figure 1 Posteroanterior chest X-ray showing finger-in-glove appearance (branching opacities) in the left lung.
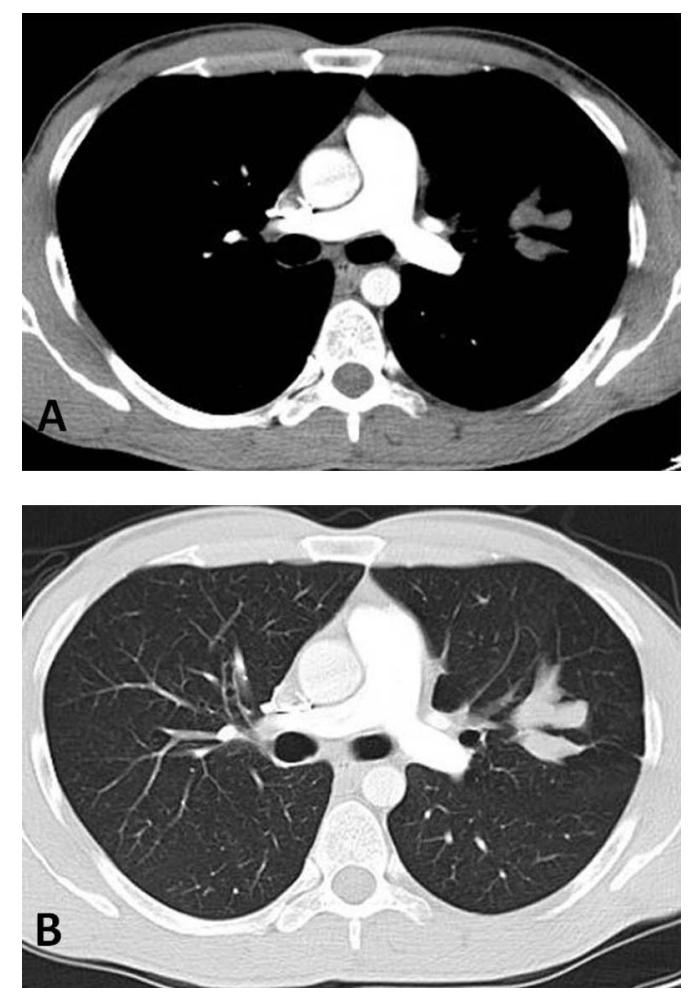

Figure 2 Contrast-enhanced axial CT images with mediastinal window $(A)$ depicting non-enhancing, branching tubular opacity. Lung window of CT (B) demonstrates hyperlucency of surrounding parenchyma of the left upper lobe.

\section{Learning points}

- Bronchial atresia is usually a benign and incidentally detected condition with a male predominance. If asymptomatic, there is no need for treatment. Surgery should be considered for symptomatic patients.

- The differential diagnosis list can be easily narrowed by knowledge of the patient's medical history and predisposing factors as well as by conducting careful clinical and radiological evaluations.

- The classical triad of bronchial atresia consists of sudden interruption of a segmental bronchus, bronchocele with a finger-in-glove appearance and hyperinflated surrounding lung areas. Cross-sectional imaging modalities can successfully demonstrate the triad and also exclude other causes, such as tumours or vascular malformations. 
and acquired origin. CT images are particularly well suited for ruling out differential diagnosis of conditions such as cystic fibrosis, allergic bronchopulmonary aspergillosis, bronchiectasis, foreign body aspiration, arteriovenous malformation or tumours. $^{2} 3$ The differential diagnosis list can be easily narrowed by knowledge of the patient's medical history and predisposing factors as well as by conducting careful clinical and radiological evaluations.

Contributors BA and MY were involved in the patient diagnosis and writing of the manuscript.
Competing interests None.

Patient consent Obtained.

Provenance and peer review Not commissioned; externally peer reviewed.

\section{REFERENCES}

1 Nussbaumer-Ochsner Y, Kohler M. Finger-in-glove sign in bronchial atresia. Thorax 2011;66:182.

2 Rajagopala S, Devaraj U, Swamy S, et al. Mucoid impaction in a 15-year-old with bronchial atresia. Respir Care 2012:57:471-3.

3 Martinez S, Heyneman LE, McAdams HP, et al. Mucoid impactions: finger-in-glove sign and other CT and radiographic features. Radiographics 2008;28:1369-82.

Copyright 2014 BMJ Publishing Group. All rights reserved. For permission to reuse any of this content visit http://group.bmj.com/group/rights-licensing/permissions.

BMJ Case Report Fellows may re-use this article for personal use and teaching without any further permission.

Become a Fellow of BMJ Case Reports today and you can:

- Submit as many cases as you like

- Enjoy fast sympathetic peer review and rapid publication of accepted articles

- Access all the published articles

- Re-use any of the published material for personal use and teaching without further permission

For information on Institutional Fellowships contact consortiasales@bmjgroup.com

Visit casereports.bmj.com for more articles like this and to become a Fellow 